\title{
Status Quo and Future Development of Sustainability Reporting in Central and Eastern Europe*
}

Péter Horváth, Judith M. Pütter,** Lina Dagilienè, Dzineta Dimante, Toomas Haldma, Cezary Kochalski, Bohumil Král, Davor Labaš, Kertu Lääts, Nidžara Osmanagić Bedenik, Renáta Pakšiová, Petr Petera, Piotr Ratajczak, Adriana Rejc Buhovac, Adriana Sava, VoicuIon Sucală, Tamás József Tirnitz, Jaroslav Wagner

Reporting on corporate social responsibility (CSR) has broadened widely within the last decade. A great deal of research on sustainability reporting (SR) has focused on American and Western Europe companies. Only fragmentary studies exist that compare reporting patterns of CEE countries. There is substantial room for investigating how and to what extend companies in CEE disclose sustainability information.

This study examined the reporting behaviour of the 50 largest companies in nine CEE countries and two WE countries in order to investigate the practice and divergence of sustainability reporting in CEE countries.

Keywords: Sustainability reporting, country comparison, Central- and Eastern Europe, CSR

\section{Introduction}

Reporting on corporate social and environmental responsibility has broadened widely within the last decade (Kolk 2008, Horváth et al. 2012). Sustainability reports are non-financial reports which provide information to all stakeholders about the organisation's involvement in Corporate Social Responsibility (CSR) issues.

* Manuscript received 05.01.16, accepted 24.03.16 (0 revisions)

** Corresponding author: Judith Pütter, IPRI gGmbH, Königstraße 5, 70197 Stuttgart, Tel.: +497116203268 8010,jpuetter@ipri-institute.com

Péter Horváth, International Performance Research Institute gGmbH (Germany)

Judith M. Pütter, International Performance Research Institute gGmbH (Germany)

Lina Dagiliene, Kaunas University of Technology (Lithuania)

Dzineta Dimante, University of Latvia (Latvia)

Toomas Haldma, University of Tartu (Estonia)

Cezary Kochalski, Poznan University of Economics and Business (Poland)

Bohumil Král, University of Economics, Prague (Czech Republic)

Davor Labaš, University of Zagreb (Kroatia)

Kertu Lääts, University of Tartu (Estonia)

Nidžara Osmanagić-Bedenik, University of Zagreb (Kroatia)

Renáta Pakšiová, The University of Economics in Bratislava (Slovakia)

Petr Petera, University of Economics, Prague (Czech Republic)

Piotr Ratajczak, Poznan University of Economics and Business (Poland)

Adriana Rejc Buhovac, University of Ljubljana (Slovenia),

Adriana Sava, Technical University of Cluj-Napoca (Romania)

Voicu I. Sucala, University of Exeter (United Kingdom)

Tamás József Tirnitz, Corvinus University of Budapst (Hungary)

Jaroslav Wagner, University of Economics, Prague (Czech Republic)

JEEMS, 22 (2) 2017, $221-243$

DOI: 10.5771/0949-6181-2017-2-221 
Despite the general increase in sustainability reporting (SR), significant differences with regard to individual countries remain (Fifka/Drabble 2012). Reporting on CSR is largely on a voluntary basis, the new European Union (EU) directive 2014/95/EU on disclosure of non-financial data applies only to companies with more than 500 employees. The requirements of the directive further allow companies a wide room for manoeuvre. The directive leaves significant flexibility for companies to disclose relevant information in the way that they consider most useful, or in a separate report. Therefore it is not surprising that extent, form and content of SR varies all over Europe (KPMG 2013). Findings from previous studies show that despite the general increase in SR, significant differences with regard to individual countries remain, even among such similar systems as the United States and Western Europe (Habisch, Jonker, Wegner, \& Schmidpeter 2004, Matten \& Moon 2004) or even if they belong to the same political and geographical region (Fifka \& Drabble 2012). It further raises the assumption that cultural and socio-economic factors that vary from country to country have an impact on reporting practices.

A great deal of research on SR has now been conducted in Western countries, but only a relatively small number of studies have focused on Central and Eastern Europe (CEE). Prior studies reveal that companies in CEE are lagging behind actual reporting practices in Western Europe (WE) (Fifka 2011, KPMG 2011, 2013). However little information exists concerning the development of SR within this region.

Compared to the rest of the world it is often assumed that there are little differences between CEE countries. While these countries do share many similarities there are also cultural and socio-economic factors that may affect SR made by companies in these countries. There is substantial room for investigating how and to what extent companies in CEE disclose sustainability information, as the "small number on studies available does hardly allow any conclusion" (Fifka 2011). Questions also arise: Does SR vary among CEE countries in comparison to WE? If so, how can differences be explained?

The following study seeks to address this research gap. It aims to provide an overview of the status quo of SR in CEE and to examine the impact of national factors. To compare reporting practices of companies in CEE region we selected the 50 largest companies, according to turnover, in each country. Overall, we compared ten CEE companies and supplemented two WE countries -- namely Germany and Austria -- to the sample, in order to investigate if there is any Central and Eastern European SR pattern.

\section{Literature Review}

CEE has witnessed enormous changes in the past. With the fall of the communist regimes, countries there have made a transition from state-controlled 
economies to open-free-market economies since 1990 (Ismayr et al., 2010). The countries in CEE started their transition from different initial positions and then pursued remarkably different policies (Berglöf \& Pajuste, 2005). Although their economic systems are rapidly converging today, the CEE region is far from being homogenous (Aidukaite 2011).

With regard to the CEE region, SR and research on SR is still at the beginning (Fifka 2011, 2012; Wensen et al. 2011) and only a small number of studies are available. The slow development of SR results from the socialist past, which made "social responsibility and social caring [. . . ] the primary role of government" and led businesses to limit their responsibility to operating "in compliance with the legal and regulatory environment" (Line \& Braun, 2007).

Studies from Osmanagic-Bedenik \& Labas $(2010,2011)$ for example have focused on CSR in Croatian companies. Both Hąbek (2014) and Hys et al. (2012) gave an overview about current SR practice in Poland. The analyses indicate that SR is not widespread among Polish companies. Babič and Biloslavo (2011) analysed sustainability reporting by Slovenian companies and found similar results for Slovenian organisations. The study of Gurvitsh and Sidorova (2012) examined social and environmental accounting disclosures in the annual reports of companies listed at Tallinn Stock Exchange. The paper of Dagilienè and Leitoniené (2012) and Dagiliene and Gokiené (2011) analyses issues of corporate social reporting development in Lithuania. Although Lithuania takes place in social accounting and reporting, the development is slow. Karcagi-Kovats (2012) gave an overview about sustainability reports in Hungary where SR is a "relatively new phenomenon" (p.1). Spassova (2007) analysed SR in Bulgaria and observed that companies surveyed disclose more information on corporate governance than on environmental and social policy, whereby online reporting has been analysed. In the case of Romania, Alin et al. (2011) analysed environmental reporting reported by Romanian listed companies and found that although there is an increase in reports, information is often incomplete and irrelevant.

The single studies mostly describe the status quo of SR in the regarded country. Based on these studies, it can be assumed, that SR is still a new phenomenon and has only recently developed, although EU accession, foreign ownership, competitive advantage and the influence of corporate governance codes motivated sustainable management practices (Baskin 2006).

Comparative studies between CEE countries and/or other regions barely exist, so no conclusion can be made. Exceptions are Jindrichovska and Purcarea (2011), Alin et al. (2011) and Golob and Bartlett (2007). The study by Steurer and Konrad (2009) gives a good overview about the understanding of CR of some major CEE companies that are leaders in SR but does not explain the reasons for differences. 


\section{Hypothesis Development}

\section{Economic Development}

Analysing the economic development of the CEE region, the countries can be divided into two groups in terms of the volatility of the growth rate. The first group is composed of the four Visegrád-countries (The Czech Republic, Hungary, Poland, Slovak Republic) and Slovenia, while the second group includes the Baltic States, Romania, and Bulgaria. The growth rate of the first group was less volatile due to a more moderate GDP decline than in the second group both during the transformation crisis and in the course of the current global economic crisis (Dombi 2013). Strong economic ties established by the first group to WE greatly influenced the initial positive economic growth, while the slow rural urban modernisation of Bulgaria and Romania may have hindered a rapid catching up process.

The different effects of the global economic crisis on the two groups of countries can be explained by the differences in the growth models followed after the transformation crisis. Becker et al. (2010) emphasised that the growth rate surge in the Baltic States, Romania and Bulgaria, was fuelled by the excessive internal consumption motivated by lending and therefore, was accompanied by a high level of external debt. In contrast, the faster growth of the other group, with the exception of Hungary, was linked with cautious policies in macroeconomic, foreign direct investments and export structures (Dombi, 2013).

Nowadays, income across the CEE economies shows a wide discrepancy ranging from 5,500€ in Bulgaria, the least economically developed country, to $17,100 €$ per capita in Slovenia (Statista 2014). Since the crisis, GDP growth in most CEE economies has been depressed.

In previous studies the economic system has been proven to be a relevant determinant of sustainability reporting (Chapple \& Moon 2005; Islam and Deegan 2008). A more stable and healthier economic environment is expected to facilitate and/or pressure companies to produce sustainability reports. Further it is assumed that higher levels of development lead to higher CSR practices because of higher levels of resources and greater awareness of issues. The study of Belal (2000) shows that this is especially true for CSR reporting. This assumption is in contrast to Guthrie and Parker and also Branco and Rodrigues (2008) who could not find a relation between SR and economic development. In order to test the contradictory results for the CEE region we hypothesise:

H1: SR in CEE is dependent on the economic development 


\section{Globalisation level}

In line with the economic development significant differences on the globalisation level can be found in CEE. It is usually stressed that globalisation processes are important in the case of transition economies. When the CEE transformed, foreign direct investments (FDI), as one expression for globalisation, was a vital factor at the initial stage of the privatisation process during the transition period. As the privatisation and restoring process came to an end, the main reasons to pursue FDI and therefore increase the globalisation level were to boost productivity, encourage employment, stimulate innovation and technology transfer, and to enhance sustained economic growth (Kornecki 2010).

Globalisation can be caused either by technological progress which reduces transport costs and improves information flows or by economic and policy changes focused on reduction of protectionism, liberalisation of foreign investment and migration rules. In the case of FDIs, transition-specific factors, economic development, economic reforms, exchange rate regime, wage differentials, the speed with which market-oriented and legal reform were introduced and the privatisation process of each country have been significant influence factors (Carstensen and Toubal 2004; Mateev and Tsekov, 2012, Albulescu and Briciu 2011). In addition, transition-specific factors, such as the level and method of privatisation and the country risk, play important roles in determining the flows of FDI into the CEE countries. These factors help to explain the differing attractiveness of the individual countries to foreign investors. According to Steurer et al (2012) the spread of CSR and CSR activities across Europe currently "depends on economic integration, globalisation and societal learning". Globalisation is changing the behaviour of economic actors (Gullién 2001).

Components for measuring the extent of globalisation are for example foreign direct investments (FDIs). Multinational corporations (MNC), the engines of world trade and drivers of FDIs, have long been criticised for their lack of social and environmental responsibility (Gray 1998; Korten 2015). Their irresponsible behaviour may eventually lead to the worldwide erosion of social and environmental standards, more marked social asymmetries and the permanent damage to the environment (Gray 1998). Nowadays it is argued that SR has become so widespread because of the international spread of activities of MNCs (Kolk 2004). As the most influential and visible companies they have often been targeted to show their commitment and to report their activities (Kolk 2005). Further FDIs are credited with a major potential in promoting sustainable development by transferring environmentally friendly technologies and know-how to host countries, raising awareness and educating consumers on social and environmental problems (Levy 1995). We assume that the globalisation level positively influences CSR and CSR activities. Therefore we hypothesise:

\section{H2: $\quad$ SR is dependent on globalisation level}




\section{Civil Society}

Next to impressive changes in economical and political processes and the rapid GDP growth within 20 years of transition, the CEE countries also developed differently with regard to their civil society. Much of the literature on civil society confirms that civil society in CEE has remained weak compared to their counterparts in established democracies (Kutter \& Trappmann 2010; Nalecz \& Bartkowski 2006; Badescu et al 2004; Howard 2003).

In examining post-communist countries, it becomes clear that civil society is resistant in a few countries and fragile in others. Previous studies and works on the post-communist era argue that socioeconomic factors and the communist legacy have weakened post-communist civil society (Zakaria 2013, Ekiert \& Foa 2011). This is partially explained by the communist legacy of distrust of organisations. The environment of distrust can be deduced from the communist era. Participation in state-controlled organisations was mandatory (Zakaria 2013). Prior research also suggests that the legacy of communism has also undermined the development of civil society in Central and Eastern Europe (Line \& Braun 2007). However, this theoretical argument is no longer plausible because it has been years since the first democratic transition took place (Zakaria 2013). "A new, post-communist generation, which does not have the same legacy and experience of communism as its predecessors, is now active in civil society" (Zakaria 2013: 3). Consequently, it is expected that the new, post-communist generation will behave differently toward civil society. Within the CEE, social potential of the civil society varies. According to Nalecz \& Bartkowski (2006) social potential is the highest in Slovenia and Croatia, followed by Hungary, the Czech Republic and Poland, and lastly the Baltic States.

It has been often asserted that the civil society is an important driver of CSR practice and there is evidence that NGO tactics have been a major driver for companies to organise CSR initiatives (Moon 2007; Warhurst 2001). Kolk (2010) has investigated the national and sector influences on the volume of sustainability reporting. Expectations in her results state that besides regulation, social context is assumed to play an important role. Besides Kolk (2010), Vormedal and Ruud (2009) showed in their study that societal drivers are one main factor influencing the level of SR.

The representative role of civil society groups and organisations ensure outcomes that reflect a wide spectrum of public opinion (Dahl 1961). The density of civic organisations, and in particular membership of organisations such as labor unions, business groups, or groups that represent salient social issues, competition among organisations and normative pluralism is therefore an indicator of the health of civic life. 
The interest of civil society organisations in SR is associated with the principle of transparency (Waddock 2008). This is the disclosure of information that is relevant and sufficient to allow stakeholders to monitor corporations' activities and impacts on different CSR themes. Further civil society organisation can mobilise consumer communities and other interest groups and drive change by using a mix of strategies such as lobbying, campaigns and legal partnership among others. Therefore we hypothesise:

\section{H3: $\quad$ SR is dependent on civil society}

\section{Cultural differences}

CEE is often seen as a region, therefore cultural differences present in CEE context have often been neglected. Despite this assumption, the reality is that CEE is fragmented and culturally diverse. This could be explained by the wide geographical spread, but also in different roots which are reflected by the language and prevailing religion in each country. The majority of the CEE countries belong to the Slavic group of languages - Czech, Slovak, Polish, Croatian and Bulgarian. Latvian and Lithuanian belong to the Baltic group, while the Romanian language has Latin origins and is very close to Italian and Spanish. Hungarian and Estonian languages belong to Finno-Ugric group (Dimitrova et al. 1998; White et al. 2007). Regarding their religion, CEE can be divided into mainly Orthodox (Bulgaria and Romania), predominantly Catholics (Poland, Czech Republic, Slovak Republic, Lithuania, Croatia) and predominantly Lutherans (Estonia, Latvia).

Differences in culture are also reflected by Hofstede's cultural dimension. Hofstede originally discovered four dimensions: power distance, individualism, uncertainty avoidance and masculinity-femininity (Hofstede 1984, 2001). Power distance refers to the degree of inequality of power within a country and the degree of acceptance by the members of the organisation to such an unequal distribution of power (Hofstede 2001). Uncertainty avoidance deals with the way a society deals with ambiguity and situations with unknown outcomes or consequences (Hofstede 2001). The dimension of individualism versus collectivism addresses the degree of interdependence that a society maintains among its members. A society that favours collectivity has its members integrated in groups early in their lives. The fourth dimension, masculinity vs. femininity, describes the spectrum of assertive behaviour (Scholtens and Dam 2007). A high degree of masculinity indicates that the society is driven by material success and would prefer higher pay than leisure time.

"Culture influences moral values, which one would expect in turn to influence at least the issues which companies select as being worthy of report" (Chen \& Bouvain 2009: 302). According to Hofstede (1983), culture is the collective pro- 
gramming of the mind, which distinguishes the members of one group or category of people from another. Thus, it is learned through a process of social construction within the social environment (nations, families, organisations) and not inherited. CSR is a socially constructed concept, and thus cannot be universally defined (Dahlsrud 2008). Consequently, culture of the nation significantly affects the development and application of SR within individual organisations (Gjølberg 2009). Also Ho et al. (2012) investigated that culture is one of the most important determinants in national ethics, and found empirical evidence to be significant in explaining ethical attitudes, ethical sensitivity, value system, ethics judgments, ethical decision-making and ethical perception.

Lewis and Unerman (1999) introduced the notion of ethical relativism which implies that ethical rules differ per country and each individual lives by their own rules. Ethical relativism is the opposite of ethical absolutism in which moral values are absolute and are universally equal (O'Sullivan 2012). Due to the different national values, as a result of the ethical relativism, the form and likelihood of sustainability reporting is expected to differ. Lewis and Unerman (1999) do not conclude that ethical relativism is the only possible cause of differences in CR practices, however it can be assumed that ethical relativism could be an important cause as the study of Gray et al. (1995) have shown. They found that the volume and nature of CSR reporting varies between countries as some issues considered important in one country are considered less important in other countries. Therefore we assume:

\section{H4: $\quad$ SR is dependent on culture}

\section{CEE pattern of SR}

Sustainability Reports (CSR-Reports) are non-financial reports which provide information to all stakeholders about the organisation's involvement in Corporate Social Responsibility (CSR) issues. ${ }^{1}$ The GRI defines sustainability reporting as "... the practice of measuring, disclosing and being accountable to internal and external stakeholders for organisational performance towards the CSR" (GRI 2013). CSR is often regarded as a universal concept evolving around the normative core of the triple bottom line framework. This framework goes beyond the traditional measures of profits, return on investments and shareholder value to include environmental and social dimensions (s. Elkington 1998). However, the actual meaning of CSR is not clearly defined. It has slightly changed over time and differs between regions according to their varying socio-political and cultural conditions (Moon 2007). Prior literature and surveys emphasised, that companies in CEE countries are far behind companies from WE regarding

1 In this paper SR refers to all types of extended reporting particular stand alone reports. 
SR (Fifka 2011, KPMG 2011; Steurer \& Konrad 2009). SR is based on the understanding of CSR.

The actual meaning of CSR as described above can change between regions. Following the results of the study from Steurer and Konrad (2009), CSR issues vary between CEE and WE companies. Companies in CEE regard environmental issues as more relevant, while social issues are seen quite sceptically. This is explained by their socialist past that left behind major environmental problems and resulted in scepticism regarding social equity issues. These different perspectives may find expression in SR. We assume that companies in CEE and WE focus on various points and despite the differences between the regions, a regional pattern compared to WE can be identified. Therefore we hypothesise:

\section{H5: A regional pattern of SR in CEE exists.}

\section{Method}

Our study considers ten CEE countries. Estonia, Latvia and Lithuania belong to the Baltic States. Romania, Croatia and Slovenia are part of South Eastern Europe and the Czech Republic, Slovak Republic, Hungary and Poland belong to Central Europe. In order to compare and also to investigate if a CEE pattern of SR exists, we added two WE countries, Germany and Austria. The 50 largest companies in each country according to turnover were analysed. The companies considered belong to the manufacturing, trading, information and communication and energy industries. In the case that the company does not belong to the mentioned industries, we move down the list until we have a sample of $50 \mathrm{com}$ panies per country. Both public and private companies were included.

Each company was examined, whether or not they published a stand-alone sustainability report. In our research, we investigated the most recent stand-alone sustainability reports provided by the companies in question. The clear majority of reports we obtained were issued in 2012 (60\%), 25\% were published in 2013, and $15 \%$ had been issued before 2012. This has to do with the fact that SR are not necessarily published yearly and the period covered by this report, varies. Additionally, we examined whether annual reports and websites were used for SR if no stand-alone reports were found.

For the stand-alone reports, content analysis was selected as the method for data collection. Content analysis broadly defined is "the study of recorded human communications, such as books, websites, paintings and laws" (Babbie 2010: 333 ) and has been used widely in the empirical investigation of non-financial reporting. Next to the overall number of pages and the number of pages for each sequence, we also investigated which performance indicators had been used (Roca/Searcy 2012) and in which languages the report had been published. The analysis of the data was conducted by using a checklist with which the relevant 
information was categorised into a multi-criterion grid. All the reports were analysed by an international research team in order to bridge language barriers.

The variables for economic development, civil society organisations, globalisation and culture were obtained from various sources. In line with the largest share of recently available reports we use data for 2012, if available. Table 1 gives an overview of the classification for the countries in our study.

We measured the development of a country in three ways. For the economic development, GDP per capita has been chosen as it is the most commonly used proxy for economic development (successfully applied by Ioannou and Serafeim (2012)). Data was provided by Eurostat. For social development we take the Human Development Index (HDI) published by the UNDP. It combines statistics on average an expected years of e.g. schooling and life expectancy with income levels. A higher HDI indicates a better quality of life and economic structure therefore the higher the rank of the HDI, the higher the human development. The third measure is the Economic Freedom index (EFI) that ranks countries on the basis of indicators on how government intervention can restrict the economic relations between individuals. The EFI is published by the Heritage Foundation. Countries with a high rank are referred to be repressed, while countries with a low rank are referred to be free.

Globalisation can also be measured in several ways. We investigated the impact on SR through two proxies. The first proxy is the average level of FDI from 2005-2013 that has been provided by UNCDAT. However, globalisation is not only driven by economical factors but also by political and social integration, which should be taken into account. Therefore we used the KOF Index of Globalisation (GI) developed by Dreher (2006). The KOF Index of Globalisation (2011) is a ranking of countries based on three dimensions of globalization: economic globalization (EGI), social globalization (SGI) and political globalization (PGI).

The measurement of civil society is always problematic, it is difficult to conceptualise and operationalise (Anheier 2013). Indices available do not cover our country sample. Another proxy could be the density of civil society organisations. Beneath civil society organisation, trade unions are one huge group. We therefore take trade union density as one proxy to measure civil society. A second proxy which can be used is the corruption perception index (CPI). According to OECD and the study of Zakaria (2013), civil society plays a huge role in the battle of bribery and corruption. In the case of CEE a powerful civil society contributed to anti-corruption initiatives. Absence or light empowerment increase corruption and is an indicator for powerless civil society. Therefore we use Corruption Perception Index (CPI) as a second proxy for civil society, which is provided by Transparency International. 
For cultural factors, we apply Hofstede's cultural dimension. Hofstede (2001) proposed a definition and a scoring system for originally four cultural dimensions: power distance (PD), masculinity (MAS), individualism (IND) and uncertainty avoidance $(\mathrm{UA})^{2}$.

Table 1 shows the proxies used. We used Spearman nonparametric correlation analysis to identify a relationship.

\begin{tabular}{|c|c|c|c|c|c|c|c|c|c|c|c|c|c|c|}
\hline & \multicolumn{4}{|c|}{ Economic development } & \multicolumn{4}{|c|}{ Globalization } & \multicolumn{3}{|c|}{ Civil Society } & \multicolumn{3}{|c|}{ Culture } \\
\hline Country & $\begin{array}{l}\text { GDP per } \\
\text { capita } \\
\text { in } €\end{array}$ & HDI & EFI & FDI in mil. \$ & GI & EGI & SGI & PGI & $\begin{array}{l}\text { TUD } \\
\text { (in \%) }\end{array}$ & CPI & PD & IND & MAS & UA \\
\hline Austria & 49039 & 21 & 21 & 10179 & 4 & 16 & 4 & 5 & 27,8 & 26 & 11 & 55 & 79 & 70 \\
\hline Croatia & 13401 & 47 & 47 & 2829 & 33 & 45 & 40 & 40 & 35 & 57 & 73 & 33 & 40 & 80 \\
\hline Czech R. & 18871 & 28 & 28 & 6672 & 15 & 14 & 13 & 37 & 17 & 57 & 57 & 58 & 57 & 74 \\
\hline Estonia & 7100 & 33 & 33 & 1801 & 25 & 8 & 32 & 78 & 67,5 & 28 & 40 & 60 & 30 & 60 \\
\hline Germany & 44999 & 6 & 6 & 44164 & 22 & 48 & 15 & 17 & 18 & 12 & 35 & 67 & 66 & 65 \\
\hline Hungary & 13388 & 43 & 43 & 6159 & 9 & 7 & 21 & 22 & 16,8 & 47 & 46 & 80 & 88 & 82 \\
\hline Latvia & 15187 & 48 & 48 & 1125 & 44 & 32 & 42 & 127 & 12 & 49 & 44 & 70 & 9 & 63 \\
\hline Lithuania & 15649 & 35 & 35 & 1220 & 36 & 30 & 48 & 72 & 10 & 43 & 42 & 60 & 19 & 65 \\
\hline Poland & 13435 & 35 & 35 & 15222 & 26 & 44 & 26 & 26 & 14,6 & 38 & 68 & 60 & 64 & 91 \\
\hline Romania & 8874 & 54 & 54 & 6842 & 38 & 65 & 46 & 24 & 40 & 69 & 90 & 30 & 42 & 90 \\
\hline Slovakia & 9500 & 25 & 25 & 3235 & 19 & 17 & 16 & 46 & 17 & 61 & 52 & 110 & 51 & 77 \\
\hline Slovenia & 23317 & 37 & 37 & 667 & 30 & 33 & 33 & 53 & 24,4 & 43 & 71 & 27 & 19 & 88 \\
\hline
\end{tabular}

Table 1: Proxies used for measuring economic development, globalization, civil society and culture

In order to analyse the CEE pattern, we measured the length of the stand-alone reports and counted how much space is dedicated to different issues. We further collected KPIs used in the Stand Alone reports. To define several issues, we followed the standard of GRI that distinguishes between economic (EC), employment (EM), environmental (EN), social (SO), product safety (PS) and human rights (HR) issues.

\section{Findings and Discussion}

Table 2 shows how many companies, in the considered countries, issue a standalone report, an integrated report, disclose sustainability information in their annual report or at least on their web site. In general, the percentage of companies reporting in a stand-alone report or even an integrated report was low. However, there is a great variation in the penetration of stand-alone SR among the countries. While only two percent of the companies in both Latvia and Slovenia publish a stand-alone report, more than $54 \%$ of companies in Poland do.

2 The fifth dimension long time orientation has been added later but is not regarded in this study. 
If all activities on SR are summarised (web site reports, part of annual reports), we get a rather different picture. SR activities seem to be low in Hungary (44\%) and Austria (48\%) while companies in The Czech Republic (92\%) and Estonia $(100 \%)$ seem to be quite active. We also investigated whether findings for the penetration of SR within each country correlate with the extent of CR Global Compact Membership. We found a statistically significant $(\mathrm{p}<.001)$ but relatively low correlation has been found (Spearman correlation $\mathrm{r}=.496) .72 \%$ of global compact members are publishing a stand-alone report; others publish sustainability information in another way.

\begin{tabular}{|c|c|c|c|c|c|c|c|c|}
\hline Country & $\begin{array}{c}\text { Stand Alone } \\
\text { SR } \\
\text { (in \%) }\end{array}$ & $\begin{array}{l}\text { SR included in } \\
\text { annual report } \\
\text { (in \%) }\end{array}$ & $\begin{array}{l}\text { SR on } \\
\text { company } \\
\text { website } \\
\text { (in } \%)\end{array}$ & $\begin{array}{c}\text { IR } \\
\text { (in \%) }\end{array}$ & $\begin{array}{c}\text { SR activities } \\
\text { overall } \\
\text { (in \%) }\end{array}$ & $\begin{array}{c}\text { Member } \\
\text { of Global } \\
\text { Compact } \\
\text { (in \%) }\end{array}$ & $\begin{array}{c}\mathrm{SR} \text { in } \\
\text { national } \\
\text { language } \\
\text { available } \\
\text { (in \%) }\end{array}$ & $\begin{array}{l}\text { GRI used in } \\
\text { stand alone } \\
\text { reports in \% }\end{array}$ \\
\hline Austria & 32 & 4 & 0 & 6 & 48 & 22 & 81 & 100 \\
\hline Croatia & 18 & 6 & 28 & 0 & 52 & 12 & 77 & 56 \\
\hline $\begin{array}{l}\text { Czech } \\
\text { Republic }\end{array}$ & 16 & 54 & 22 & 0 & 92 & 0 & 88 & 25 \\
\hline Estonia & 12 & 76 & 10 & 2 & 100 & 18 & 50 & 100 \\
\hline Germany & 48 & 8 & 4 & 10 & 70 & 48 & 85,7 & 88 \\
\hline Hungary & 14 & 2 & 2 & 4 & 44 & 2 & 100 & 57 \\
\hline Latvia & 2 & 4 & 22 & 2 & 30 & 2 & 100 & 0 \\
\hline Lithuania & 30 & 16 & 0 & 0 & 46 & 16 & 53 & 7 \\
\hline Poland & 54 & 6 & 18 & 6 & 84 & 18 & 74 & 59 \\
\hline Romania & 46 & 12 & 24 & 6 & 88 & 2 & 17 & 78 \\
\hline Slovakia & 28 & 46 & 12 & 10 & 96 & 9 & 7 & 86 \\
\hline Slovenia & 2 & 54 & 0 & 0 & 56 & 10 & 100 & 100 \\
\hline
\end{tabular}

Table 2: Proxies used for measuring economic development, globalization, civil society and culture

\section{The Impact of Economic Development on SR:}

We analysed whether the level of SR Reporting is explained by individual variables of economic development, social development or economic freedom index. The significance of national levels of GNP per capita for SR was examined on the assumption that a higher wealth would reflect relatively greater resources that could be reinvested in society through CSR. There was no significant correlation between GDP per capita and SR penetration.

Two cases that underline this finding are Romania, which GDP/head is the lowest in the sample and has a high level of CSR reporting, and Poland which GDP per capita is in the middle but have the highest level of SR-penetration. We found statistically significant relationships between HDI and the penetration of SR $(p<.001)$ and EFI $(p<.05)$ but both with very low correlations $(r=.165$ and $\mathrm{r}=.119$ ). In summary, our results suggest that the hypothesis can be rejected. 




Figure 1: the relationship between GDP (in $€$ ) and SR Penetration

The Impact of Globalisation on SR165:

The impact of globalisation has been another frequently cited reason for improved corporate SR (Aras \& Crowther 2009, Kolk 2010). We investigate the relationship between globalisation and SR through FDI and the globalisation index by KOF.

We first considered the possible effect of FDI of each country on its level of SR penetration. Figure 2 provides some evidence of an association between CSR and globalisation as measured by FDI into each country (a Spearman nonparametric correlation revealed $\mathrm{r}=.830$ correlation coefficient significant at the .001 level). Here Lithuania is an anomaly. It has a high SR penetration but relatively low FDIs.

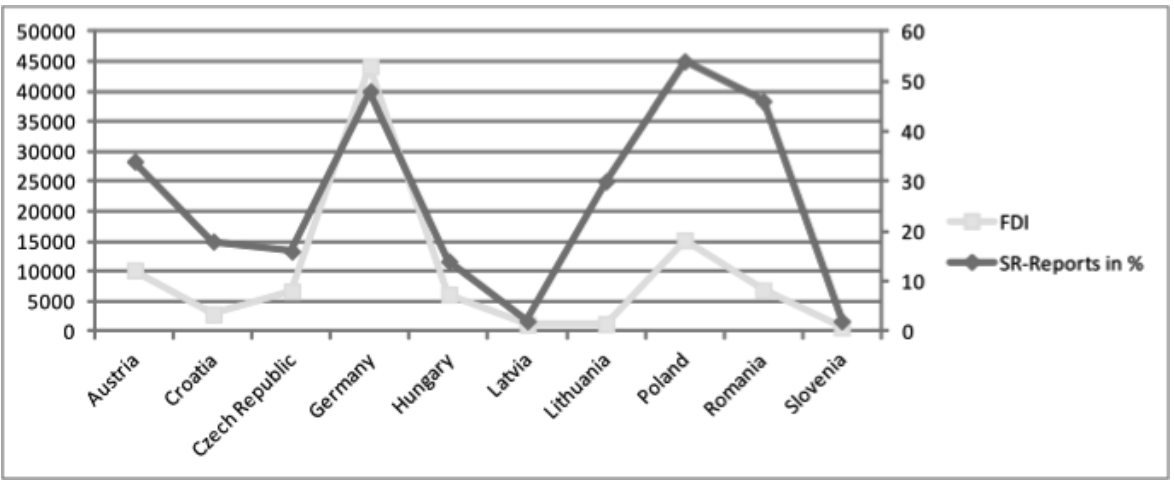

Figure 2: relationship between FDI (in €) and SR Penetration

We further analysed whether the SR penetration correlates with the overall globalisation index. For the overall globalisation index, no significant relation to the penetration of stand-alone reports has been found. However, we looked for single dimensions of the globalisation index and interestingly, the economical and 
the political dimensions of the globalisation index showed significant correlation $(-.501,-.662$ with $\mathrm{p}<.01)$. The results confirm our assumption that the extent of SR depends on the globalisation level, therefore we cannot reject hypothesis 2 .

\section{The Impact of Civil Society on SR}

We analysed whether the level of CSR reporting nationally is explained by the individual variables of the social context. We used density of trade unions and the Corruption Perception Index. There was no statistically significant correlation between the density of trade unions. However, a low correlation between Control of corruption and SR penetration $(.160 \mathrm{p}<.001)$ has been found on CPI and the penetration of SR reports and on EPI and penetration of SR reports. The results match with several studies, where the authors argue that civil society does not play an important role anymore and are rather weak (Howard 2003). Further civil society organizations are hardly recognized as stakeholders by CEE companies. "The awareness, ability and organizational power of NGOs to put pressure on business and government" is according to the UNDP baseline study $(2007,31)$ limited. Hypothesis 3 can be rejected.

\section{Influence from cultural factors}

Turning to the fourth hypothesis, we investigated whether SR is enhanced by culture. We assumed that a relation between cultural factors and the extension of SR exists. We investigate the relation between Hofstede's cultural dimension and SR in CEE: For two out of four dimensions we find a significant but low correlation. The highest correlation has been found for MAS $(r=-.359$, significant at the level $\mathrm{p}<.001)$ followed by UAI $(\mathrm{r}=.358$ significant at the level $\mathrm{p}<$. 001).

With UAI Hofstede means the level of acceptance of uncertainty and ambiguity for a given country. A high score is indicative of a society that is rule-oriented, i.e. seeks to reduce the amount of uncertainty. Uncertainty can be reduced by implementing more rigid and standardised modes of action such as normative reporting incorporating in order to avoid scarce sustainability information. Prior research (e.g., Katz et al. 2001) suggests that a country with higher ranks in "uncertainty avoidance" is likely to be ranked highly in terms of environmental activism and therefore more likely to publish sustainability reports. A higher level of uncertainty avoidance has therefore been expected to be associated with more sustainability reports.

The dimensions MAS stand for assertiveness and competitiveness. Greater masculinity in a society is related to a weaker social orientation while a low-masculine society is a socially orientated society. Masculinity is linked to values of success and earnings where economic disclosures will be prioritized (Garcia- 
Sanchez et al. 2013). As the relationship between SR and MAS is negative, it confirms the assumption that a low rank in MAS is accompanied by a higher extent of SR. As we have found significant but weak relationship between two out of four dimensions and the extent of SR we cannot reject hypothesis 4.

\section{CEE patterns of $S R$}

We assumed to find a CEE pattern for SR. To analyze regional differences, we divided CEE in the sub regions South East Europe (Croatia, Romania and Slovenia), in Central Europe (Czech Republic, Slovak Republic, Hungary and Poland) and the Baltic States (Estonia, Latvia and Lithuania) and compared them to WE (Austria and Germany). We find a nearly similar distribution of reports in the South Eastern Europe and Central Europe, with the Baltic States as an exception. On average, reports in WE are longer than reports in CEE. The Baltic States publish relatively short SR also in comparison to the other CEE sub regions.

According to the number of pages (presented as the average share) and KPIs used, no CEE pattern has been found (s. Table $3 \&$ Table 4). We assumed that due to the historical past, SR in CEE does emphasize more on environmental issues. Central and South East European companies dedicate environmental issues more space than other issues, followed by employment issues. Similar applies for the KPIs used. 30\% of all KPIs in South Eastern European companies respectively $41 \%$ in Central European companies belong to the environmental part. The result in case reflects the outcome of the study from Konrad and Steurer (2009), that companies in CEE see environmental issues as more relevant. Interestingly South European companies publish more KPIs on product safety than any other region.

Further the Baltic States do not follow this pattern and place more emphasis on social issues, while economic issues have less space than environmental and social issues (number of pages as well as KPIs used). In Western Europe particular attention comes to environmental issues, followed by economical and then by employment issue if only the number of pages would have to be taken into account. The share of KPIs reflects another picture: KPIs on employment issues is the highest followed by environmental and economical KPIs.

All regions have in common that issues on product safety and human rights play a minor role. Companies often refer to legal compliance and do not go beyond to general commitments in reporting. 


\begin{tabular}{lcccccccccc}
\hline Region & $\begin{array}{l}\text { Stand Alone } \\
\text { SR Report }\end{array}$ & $\varnothing$ & min & max & $\begin{array}{c}\text { Ec } \\
\text { (in \%) }\end{array}$ & $\begin{array}{c}\text { Em } \\
\text { (in \%) }\end{array}$ & $\begin{array}{c}\text { En } \\
\text { (in \%) }\end{array}$ & $\begin{array}{c}\text { SO } \\
\text { (in \%) }\end{array}$ & $\begin{array}{c}\text { PS } \\
\text { (in \%) }\end{array}$ & $\begin{array}{c}\text { HR } \\
\text { (in \%) }\end{array}$ \\
\hline $\begin{array}{l}\text { Western } \\
\text { Europe }\end{array}$ & 38 & 93 & 23 & 280 & 11,6 & 11,3 & 17,04 & 7,3 & 4,6 & 0,64 \\
$\begin{array}{l}\text { South Eastern } \\
\text { Europe }\end{array}$ & 33 & 85 & 5 & 558 & 5,5 & 10,6 & 18,5 & 8,0 & 5,5 & 2,3 \\
$\begin{array}{l}\text { Central } \\
\text { Europe }\end{array}$ & 45 & 80 & 14 & 166 & 12,7 & 13,6 & 17,2 & 12,6 & 5,1 & 1,5 \\
Baltic States & 15 & 33 & 8 & 102 & 2,9 & 7,79 & 5,8 & 5,53 & 1,33 & 1,1 \\
\hline
\end{tabular}

Table 3: CEE pattern of SR - number of pages

\begin{tabular}{lccccccccc}
\hline Region & $\begin{array}{c}\text { KPIs } \\
\varnothing\end{array}$ & min & max & $\begin{array}{c}\text { Ec } \\
\text { (in \%) }\end{array}$ & $\begin{array}{c}\text { Em } \\
\text { (in \%) }\end{array}$ & $\begin{array}{c}\text { En } \\
\text { (in \%) }\end{array}$ & $\begin{array}{c}\text { SO } \\
\text { (in \%) }\end{array}$ & $\begin{array}{c}\text { PS } \\
\text { (in \%) }\end{array}$ & $\begin{array}{c}\text { HR } \\
\text { (in \%) }\end{array}$ \\
\hline $\begin{array}{l}\text { Western Europe } \\
\begin{array}{l}\text { South Eastern } \\
\text { Europe }\end{array}\end{array}$ & 55 & 0 & 73 & 23 & 32 & 30 & 9 & 5 & 0,25 \\
$\begin{array}{l}\text { Central Europe } \\
\text { Baltic States }\end{array}$ & 50 & 0 & 143 & 14 & 25 & 41 & 10 & 9 & 0 \\
\hline
\end{tabular}

Table 4: CEE-pattern of SR - KPIs

\section{Conclusion}

The aim of the study was to give an overview over the status quo of SR in CEE countries and to explain difference in corporate SR. Overall penetration and form of sustainability reporting varies considerably in CEE. The percentage of companies that issue a stand-alone report is all over quite low, not only in the CEE but also in WE. This result reflects also the observations of several other studies (Stubbs et al. 2012) that discovered that only the largest companies worldwide do such kind of reporting.

The proportion of stand-alone SR was highest in Poland, followed by Germany and Romania. This is in line with the results of the KPMG study of 2013. It describes that Romania had one of the highest growth rates of all regarding countries since 2013 in SR. Only a few stand-alone reports have been found in Latvia and Slovenia, where companies preferred to publish sustainability data included in their annual report or in the case of Latvia on their website without following a certain standard.

Our research contributes to the current academic literature as it is the first one to provide data about sustainability reporting in several Central and Eastern European countries. Calls from prior research stated the need to understand global SR practices in other countries than yet done (Fifka 2012). As the penetration and form of SR varies considerably in CEE, we further investigated the influence of several factors on the extent of stand alone reports. In our sample, glob- 
alisation and culture seems to be an influential factor, while we could not find any relation between economic development and civil society and the extent of stand-alone reports.

Secondly we investigated priorities and weighting of the sustainability perspectives within SR in order to recognize a CEE pattern in SR. We could not find a certain CEE pattern of SR. One reason could be that the alignment of reports increases due to the fact, that reporting standards like the standard from the Global Reporting Initiative are increasingly establishing themselves (Hahn \& Kühnen 2013). Furthermore many multinational companies were among the sample. In case they publish a sustainability report, they locally adjust the content however the concept and structure remain the same "worldwide", so that no special pattern have the chance to emerge (Kolk 2012). The same applies to social accounting (de Villiers \& Alexander 2014).

Despite the new EU directive SR is still voluntary for most of Central- and Eastern European companies, as it concerns only the biggest companies. Previous studies reveal that reports on sustainability may increase transparency and the attractiveness on investments as the disclosure of non financial data are positive associated with the financial performance of a company (SchmalenbachGesellschaft 2014). The lack of standardization of SR and the ability to publish sustainability data in different media makes SR incomparable and less transparent (Roca \& Searcy 2012). In order to raise the attractiveness on investments and to support the homogeneity of SR governments of the regarded countries should influence and improve reporting environments by providing guidelines. These guidelines must especially consider the special need of the smaller not multinationalized companies of each country.

The lack of a CEE-pattern reveals that either no CEE-patterns exists and the expectations of stakeholders are Europe-wide the same or companies ignore special expectations of each country in order to follow a centralized strategy (Muller 2006). As we analyzed that culture may have an influence on SR managers should also take into account that requirements on SR will be differently in every country. In order to investigate what is really expected from national stakeholders and which topics are relevant, they may acquire relevant knowledge ad train specialist. Also further research is needed instead of taking over established concepts that worked in other countries.

There are numerous possibilities for future research in this area. For example, future research could go beyond content analysis of stand-alone sustainability reports. The disclosure of indicators on corporate websites, in annual reports, and in other forms could be explored. Questionnaires could be used to explore in greater depth how the usefulness of the GRI indicators is perceived in corporations. Interviews would allow corporate managers to explain their approach to many questions, such as how the indicators were selected for disclosure in the 
report, how the indicators relate to corporate strategy and so on. Further the emphasis reflected by the number of pages has not been accompanied by the share of KPIs. Based on prior research this could be one further indication for uneven disclosure. Deegan \& Gordan (1996) found, that companies that have a high impact on environment disclosed more information on social responsibility. The same might apply for "hard facts" in SR. Even if a company highlights a special focus e.g. on environment in their report, they may disclose more information on a topic that makes them look better.

Other topics for further research could be to explore the association between globalisation and CSR in more detail. We did not take the origin of the company and the expectation of stakeholders in the country of origin into account that may also affect the SR activities in other countries.

This article has provided some initial, empirically based findings on which further research can be built.

\section{References}

Aidukaite, J. (2011) Welfare reforms and socio-economic trends in the 10 new EU member states of Central and Eastern Europe. Communist and Post-Communist Studies, 44(3), 211-219.

Albulescu, C. T., \& Briciu, L. (2011). FDI inflows in CEECs and financial system stability. Poitiers University, CRIEF and West University of Timisoara, Working paper, 11.

Alin, I.,/Muller, V./Dumitru, M. (2011). Environmental reporting within the Romanian companies. International Journal of Energy and Environment, 5(1), 123-131.

Anheier, H. (2013). Civil Society:" Measurement, Evaluation, Policy": Routledge.

Arbeitskreis Externe Unternehmensrechung der Schmalenbach-Gesellschaft (2015). Nichtfinanzielle Leistungsindikatoren - Bedeutung für die Finanzberichterstattung. Zfbf, Mai 2015, 235-258.

Babič, S. F/ Biloslavo, R. (2011). Corporate Sustainability Reporting: Opportunities and Challenges in a Post-Transition Country. Paper presented at the Managing Sustainabilty, Slovenia.

Babbie, E. (2010). The practice of social research: Cengage Learning.

Bădescu, G., Sum, P., \& Uslaner, E. M. (2004). Civil society development and democratic values in Romania and Moldova. East European Politics \& Societies, 18(2), 316-341.

Baskin, J. (2006). Corporate Responsibility in Emerging Markets. Journal of Corporate Citizenship, 2006(24), 29-47.

Becker, T., Daianu, D., Darvas, Z., Gligorov, V., Landesmann, M., Petrovic, P., di Mauro, W. (2010). Whither growth in Central and Eastern Europe? Policy lessons for an integrated Europe. Bruegel Blueprint Series No. 11, November 2010.

Belal AR. 2000. Environmental reporting in developing countries: empirical evidence from Bangladesh. Eco-Management and Auditing 3: 114-121.

Berglöf, E./Pajuste, A. (2005). What do firms disclose and why? Enforcing corporate governance and transparency in Central and Eastern Europe. Oxford Review of Economic Policy, 21(2), 178-197. 
Branco, M. C., \& Rodrigues, L. L. (2008). Factors influencing social responsibility disclosure by Portuguese companies. Journal of Business Ethics, 83(4), 685-701.

Carstensen, K., \& Toubal, F. (2004). Foreign direct investment in Central and Eastern European countries: a dynamic panel analysis. Journal of comparative economics, 32(1), 3-22

Chen, S./Bouvain, P. (2009). Is corporate responsibility converging? A comparison of corporate responsibility reporting in the USA, UK, Australia, and Germany. Journal of Business Ethics, 87(1), 299-317.

Dagiliene, L./Gokienè, R. (2011). Valuation of corporate social responsibility reports. Economics and Management (16), 21-27.

Dagilienè, L./Leitoniené, Š. (2012). Corporate social reporting development in Lithuania. Economics and Management, 17(4), 1233-1239.

Dahlsrud, A. (2008). How corporate social responsibility is defined: an analysis of 37 definitions. Corporate Social Responsibility and Environmental Management, 15(1), 1-13.

Deegan, C., \& Gordon, B. (1996). A study of the environmental disclosure practices of Australian corporations. Accounting and business research, 26(3), 187-199.

Dimitrova, L./Ide, N./ Petkevic, V./ Erjavec, T./ Kaalep, H. J./Tufis, D. (1998). Multext-east: Parallel and comparable corpora and lexicons for six central and eastern european languages. Paper presented at the Proceedings of the 36th Annual Meeting of the Association for Computational Linguistics and 17th International Conference on Computational Linguistics-Volume 1.

fthe Transformation. Public Finance Quarterly, 58(4), 452-468.

Dreher, A. (2006). Does globalization affect growth? Evidence from a new index of globalization. Applied Economics, 38(10), 1091-1110.

Ekiert, G./Foa, R. (2011). Civil Society Weakness in PostCommunist Europe: A Preliminary Assessment. Carlo Alberto Noteboooks.-2011.-URL: www. carloalberto. org/working_papers.

Elkington, J. (1998). Cannibals With Forks: The Triple Bottom Line of 21st Century Business: New Society Publishers.

Fifka, M. S. (2011). Corporate Responsibility Reporting and its Determinants in Comparative Perspective - a Review of the Empirical Literature and a Meta-analysis. Business Strategy and the Environment, 22(1), 1-35.

Fifka, M. S. (2012). The development and state of research on social and environmental reporting in global comparison. Journal für Betriebswirtschaft, 62(1), 45-84.

Fifka, M. S./Drabble, M. (2012). Focus and Standardization of Sustainability Reporting - A Comparative Study of the United Kingdom and Finland. Business Strategy and the Environment, 21(7), 455-474.

García-Sánchez, I.-M., Rodríguez-Ariza, L., \& Frías-Aceituno, J.-V. (2013). The cultural system and integrated reporting. International Business Review, 22(5), 828-838

Gjølberg, M. (2009). Measuring the immeasurable?: Constructing an index of CSR practices and CSR performance in 20 countries. Scandinavian journal of management, 25(1), 10-22.

Global Reporting Initiative, (GRI). (2013). Sustainablity reporting guidelines, Version G4, https://www.globalreporting.org/standards/g4/Pages/default.aspx 
Golob, U./Bartlett, J. L. (2007). Communicating about corporate social responsibility: A comparative study of CSR reporting in Australia and Slovenia. Public Relations Review, 33(1), $1-9$.

Gray, H. P. (1998). International trade and foreign direct investment: the interface. In J. H. Dunning (Ed.), Globalization, trade and foreign direct investment (pp. 19-27). Oxford: Elsevier.

Gray, R./Kouhy, R., \& Lavers, S. (1995). Corporate social and environmental reporting: a review of the literature and a longitudinal study of UK disclosure. Accounting, Auditing \& Accountability Journal, 8(2), 47-77.

Gurvitsh, N./Sidorova, I. (2012). Survey of Sustainability Reporting Integrated into Annual Reports of Estonian Companies for the Years 2007-2010: Based on Companies Listed on Tallinn Stock Exchange as of October 2011. Procedia Economics and Finance, 2, 26-34.

Hąbek, P. (2014). Evaluation of sustainability reporting practices in Poland. Quality \& Quantity, 48(3), 1739-1752.

Habisch, A., Jonker, J., Wegner, M., \& Schmidpeter, R. (2005). Corporate social responsibility across Europe: Springer Science \& Business Media.

Hahn, R., \& Kühnen, M. (2013). Determinants of sustainability reporting: A review of results, trends, theory, and opportunities in an expanding field of research. Journal of Cleaner Production, 59, 5-21.

Ho, F. N./Wang, H.-M. D./ Vitell, S. J. (2012). A global analysis of corporate social performance: The effects of cultural and geographic environments. Journal of Business Ethics, 107(4), 423-433.

Hofstede, G. (1984). Culture's consequences: International differences in work-related values (Vol. 5): sage.

Hofstede, G. (2001). Culture's consequences: Comparing values, behaviors, institutions and organizations across nations: Sage.

Horváth, P./Isensee, J./Michel, U. (2012). „Green Controlling“ - Bedarf einer Integration von ökologischen Aspekten in das Controlling. In M. Tschandl \& A. Posch (Eds.), Integriertes Umweltcontrolling (pp. 41-50): Gabler Verlag.

Howard, M. M. (2003). The weakness of civil society in post-communist Europe: Cambridge University Press.

Hys, K./ Hawrysz, L./Opole, T. (2012). Corporate social responsibility reporting. China-USA Business Review, 11(11), 1515-1524.

Ioannou, I., \& Serafeim, G. (2012). What drives corporate social performance; The role of nation-level institutions. Journal of International Business Studies, 43(9), 834-864.

Islam, M. A., \& Deegan, C. (2008). Motivations for an organisation within a developing country to report social responsibility information: evidence from Bangladesh. Accounting, Auditing \& Accountability Journal, 21(6), 850-874.

Ismayr, W./Richter, S./Söldner, M. (2010). Die politischen Systeme Osteuropas: Springer.

Jindrichovska, I./Purcarea, I. (2011). CSR and environmental reporting in the Cech Republic and Romania: Country comparison of rules and practices. Accounting and Management Information Systems, 10(2), 202-227.

Karcagi-Kovats, A. (2012). Performance indicators in CSR and sustainability reports in Hungary. Applied Studies in Agribusiness and Commerce, 6. 
Katz, J. P., Swanson, D. L., \& Nelson, L. K. (2001). Culture-based expectations of corporate citizenship: A propositional framework and comparison of four cultures. The International Journal of Organizational Analysis, 9(2), 149-171.

Kolk, A. (2004). A decade of sustainability reporting: developments and significance. International Journal of Environment and Sustainable Development, 3(1), 51-64.

Kolk, A. (2005). Environmental reporting by multinationals from the Triad: convergence or divergence? MIR: Management International Review, 145-166.

Kolk, A. (2008). Sustainability, accountability and corporate governance: exploring multinationals' reporting practices. Business Strategy and the Environment, 17(1), 1-15.

Kolk, A. (2010). Trajectories of sustainability reporting by MNCs. Journal of World Business, 45(4), 367-374.

Kornecki, L. (2010). Foreign direct investment and macroeconomic changes in CEE integrating into the global market. Journal of International Business \& Cultural Studies, 3, 1-12.

Korten, D. C. (2015). When corporations rule the world: Berrett-Koehler Publishers.

KPMG. (2011). International Survey of Corporate Responsibility Reporting 2011. Retrieved from http://www.kpmg.com/Global/en/IssuesAndInsights/ArticlesPublications/corporateresponsibility/Pages/2011-survey.aspx website:

KPMG. (2013). The KPMG Survey of Corporate Responsibility Reporting 2013 Retrieved 01.09.2014, from http://www.kpmg.com/Global/en/IssuesAndInsights/ArticlesPublications/ corporate-responsibility/Documents/corporate-responsibility-reporting-survey-2013.pdf

Kutter, A./Trappmann, V. (2010). Civil society in Central and Eastern Europe: The ambivalent legacy of accession. Acta Politica, 45(1), 41-69.

Mateev, M. I., \& Tsekov, I. (2012). Do Central and Eastern European Countries Posses FDI Advantages to More Developed Western Countries? Available at SSRN 2139361.

Lewis, L., \& Unerman, J. (1999). Ethical relativism: a reason for differences in corporate social reporting? Critical Perspectives on Accounting, 10(4), 521-547.

Levy, D. L. (1995). International sourcing and supply chain stability. Journal of International Business Studies, 343-360.

Line, M./Braun, R. (2007). Baseline Study on CSR Practices in the New EU Member States and Candidate Countries. UNDP and the European Commission.[Online]. Available: http:// www. acceleratingcsr. eu/uploads/docs/BASELINE_STUDY_ON. pdf. Accessed on December, 13, 2007.

Matten, D., \& Moon, J. (2008). "Implicit" and "explicit" CSR: A conceptual framework for a comparative understanding of corporate social responsibility. Academy of Management Review, 33(2), 404-424.

Moon, J. (2007). The contribution of corporate social responsibility to sustainable development. Sustainable Development, 15(5), 296-306.

Muller, A. (2006). Global Versus Local CSR Strategies. European Management Journal, 24(2-3), 189-19.

Nalecz, S./ Bartkowski, J. (2006). Is there organizational base for civil society in Central Eastern Europe. In S. Eliaeson (Ed.), Building Democracy and Civil Society East of the Elba (Vol. 163-195). London: Routledge.

Neumayer, E., \& Perkins, R. (2004). What explains the uneven take-up of ISO 14001 at the global level? A panel data analysis. Environment and Planning A, 36, 823-839. 
Osmanagić Bedenik N./Labaš, D. (2010). Corporate social responsibility and business success in Croatian companies // EBES 2010 Conference- Athens, Program and abstract book / Bilgin M. H. ; Danis, H. (red.). Istanbul : EBES publication, 64-64.

Osmanagić Bedenik, N./Labaš D. (2011). Role of corporate social responsibility (CSR) in business planning and practice of Croatian companies. Market, 23 (2), 143-164.

O'Sullivan, P. (2012). Economic methodology and freedom to choose. New York: Routledge.

Pütter, J. M. (2014). Integrated Reporting (Controlling-Lexikon Beitrag). Zeitschrift für Controlling (ZfC), 26, 206-207.

Roca, L. C.,/Searcy, C. (2012). An analysis of indicators disclosed in corporate sustainability reports. Journal of Cleaner Production, 20(1), 103-118.

Schmalenbach-Gesellschaft. (2015). Nichtfinanzielle Leistungsindikatoren : Bedeutung für die Finanzberichterstattung. [Aufsatz in Zeitschriften, Article in journal]. Schmalenbachs Zeitschrift für betriebswirtschaftliche Forschung : Zfbf, 67(2, (5)), 235-258.

Scholtens, B., \& Dam, L. (2007). Cultural values and international differences in business ethics. Journal of Business Ethics, 75(3), 273-284.

Spassova, P. (2007). Reporting on Corporate Social Responsibility (CSR) by the Forty Largest Listed Companies in Bulgaria.

Steurer, R./Konrad, A. (2009). Business-society relations in Central-Eastern and Western Europe: How those who lead in sustainability reporting bridge the gap in corporate (social) responsibility. Scandinavian Journal of Management, 25(1), 23-36.

Steurer, R., Martinuzzi, A., \& Margula, S. (2012). Public policies on CSR in Europe: Themes, instruments, and regional differences. Corporate Social Responsibility and Environmental Management, 19(4), 206-227.

Stubbs, W./Higgins, C./Milne, M. (2012). Why Do Companies Not Produce Sustainability Reports? Business Strategy and the Environment.

Transparency International (2013): Corruption Perception Index, http://www.transparency.org/ research/cpi/overview (01.09.2014)

UNDP. (2007). Baseline Study on CSR Practices in the New EU Member States and Candidate Countries. Retrieved from http:/www.nadaciapontis.sk/tmp/asset_cache/link/ 0000016790/baseline\%20study\%20on\%20CSR\%20in\%20the\%20region_main\%20layout.pdf (24.16.2016)

Vormedal, I., \& Ruud, A. (2009). Sustainability reporting in Norway-an assessment of performance in the context of legal demands and socio-political drivers. Business Strategy and the environment, 18(4), 207-222.

de Villiers, C./Alexander, D. (2014). The institutionalisation of corporate social responsibility reporting. The British Accounting Review, 46(2), 198-212.

Waddock, S. (2008). Building a new institutional infrastructure for corporate responsibility. The Academy of Management Perspectives, 22(3), 87-108. 
Warhurst, A. (2001). Corporate citizenship and corporate social investment. Journal of Corporate Citizenship, 2001(1), 57-73.

Wensen, K. v./Wijnand, B./Klein, J./Knopf, J. (2011). The state of play in sustainability reporting in the EU.

White, S./Batt, J.,/Lewis, P. G. (2007). Developments in Central and East European Politics 4: Duke University Press.

Zakaria, P. (2013). Is corruption an enemy of civil society? The case of Central and Eastern Europe. International Political Science Review, 34(4), 351-371. (01.09.2014): Transparency International (2013): Corruption Perception Index, http://www.transparency.org/ research/cpi/overview. 